\title{
Improving the short-term efficiency of rock phosphate-based fertilizers in pastures by using edaphic biostimulants
}

\author{
L. Fernández ${ }^{1,2}$, R. Baigorri ${ }^{*}$, O. Urrutia ${ }^{2}$, J. Erro ${ }^{2}$, P. M. Aparicio-Tejo ${ }^{1}$, J. C. Yvin ${ }^{3}$ and J. M. García-Mina ${ }^{2,4^{*}}$
}

\begin{abstract}
Background: The use of reactive rock phosphate (RP) in acidic soils as a phosphate (P) source for pastures and crops presents attractive economic advantages with respect to soluble phosphate. However, some studies have demonstrated that the short-term (1-year) efficiency of RP, compared with that of water-soluble $\mathrm{P}$, is relatively poor. This fact penalizes not only the yield and quality of the earlier harvests, but even the whole final yield when the crop is affected by some abiotic or biotic stress at the beginning of the cycle. In the present study, we investigated the ability of new edaphic biostimulants to increase the short-term efficiency of RP-based fertilizer as a P source for pastures cultivated in acid soils. To this end, we have granulated rock phosphate with two edaphic biostimulants: tryptophan and a heteromolecular organic complex formed by humic acid and tryptophan through iron bridges, and compared their short-term P fertilizer efficacy with that of single superphosphate and rock phosphate.

Results: Soil incubation studies showed that the heteromolecular complex humic acid-tryptophan and Tryptophan were able to increase soil $\mathrm{CO}_{2}$ production compared with native soil, rock phosphate, and superphosphate. Likewise, the presence of humic acid-tryptophan complex and Trp significantly increases plant-available phosphate compared with rock phosphate, up to levels similar to those of superphosphate. Plant (ray grass)-soil-pot studies showed that rock phosphate/(humic acid-tryptophan) formulation yielded values for both ray grass dry matter production and shoot P concentration, clearly higher than those of rock phosphate and rock phosphate/tryptophan. In addition, the results associated with rock phosphate/(humic acid-tryptophan) were similar to those for superphosphate, after 3 months of cultivation.
\end{abstract}

Conclusions: Taken together, these results showed the suitability of the use of specific humic acid-based edaphic biostimulants to improve the short-term effect of rock phosphate fertilizers as a phosphate source for pastures cultivated in acid soils.

Keywords: Edaphic biostimulants, Rock phosphate, Phosphate fertilizer, Pastures, Plant-available phosphate soil microbial activity, Humic acid, Humic acid-based heteromolecular complexes

\section{Background}

Water-soluble phosphate (P)-based fertilizers, mainly single superphosphate (SSP) and triple superphosphate

\footnotetext{
*Correspondence: rbaigorri@timacagro.es; jgmina@timacagro.es

${ }^{2}$ Department of Environmental Biology (Agricultural Chemistry and Biology Group), Faculty of Sciences, University of Navarra, 31080 Pamplona, Spain

${ }^{4}$ Department of Environmental Biology, Agricultural Chemistry and Biology Group, Faculties of Sciences and Pharmacy, University of Navarra, C/Irunlarrea 1, 31080 Pamplona, Navarra, Spain Full list of author information is available at the end of the article
}

(TSP), are the main sources of $\mathrm{P}$ used for cultivated pastures, mainly in alkaline soils, but also in acidic soils [1, 2]. However, in pastures (and also other crops) cultivated in acidic soils, the direct application of rock phosphate (RP) (granule or powder)-without previous reaction with sulfuric and/or phosphoric acids-may be a suitable, less-expensive, alternative to water-soluble P fertilizers [1]. In addition, the slow solubilization of RP in acidic soils may also contribute to decrease environmental risks, such as the eutrophication of surface waters [3].

\section{Springer}

(c) 2016 Fernández et al. This article is distributed under the terms of the Creative Commons Attribution 4.0 International License (http://creativecommons.org/licenses/by/4.0/), which permits unrestricted use, distribution, and reproduction in any medium, provided you give appropriate credit to the original author(s) and the source, provide a link to the Creative Commons license, and indicate if changes were made. The Creative Commons Public Domain Dedication waiver (http://creativecommons.org/ publicdomain/zero/1.0/) applies to the data made available in this article, unless otherwise stated. 
However, although some authors have reported that the efficiency of RP as a $\mathrm{P}$ source for pastures cultivated in acid soils is as effective as that of SSP or TSP in long-term studies (3-4 years) $[1,4,5]$, most studies have shown that $\mathrm{RP}$ efficiency is normally lower than that of water-soluble $P$ fertilizers, with this fact being likely related to the lower short-term (1-year) efficiency of RP as a source of plantavailable P with respect to that of water-soluble P (SSP or TSP) [1].

Historically, researchers have tried to improve plantavailable P release rates from RP using several strategies. Some authors have prepared partially acidulated RP, or RP mixed with water-soluble P (TSP, SSP, or ammonium phosphates) [6-11]. Recently, other strategies included the use of stabilized phosphorus-solubilizing microorganisms (PSMs) [12-16], or plant growth-promoting rhizobacteria (PGPR) [17-19] along with or without RP.

Very recently, several studies have shown that specific enzyme-based hydrolyzed compost and protein residues, named edaphic biostimulants, are able to significantly increase the activity of most soil enzymes $[20,21]$. This action was accompanied by increases in the biodegradation of many organic contaminants and xenobiotics [21]. In this line, Renella et al. [22] showed that an edaphic biostimulant based on the heteromolecular complex between a sedimentary humic acid (HA) and tryptophan (Trp) (HA-Trp) was able to significantly increase the activity of several enzyme families (phosphatases, organic hydrolases, and proteinases) in different soil types. In fact, previous studies had shown the stimulant action of Trp on the growth of soil cultivated plants, likely through the promotion of the biosynthesis of auxin in both the rhizosphere and plants [23, 24]. However, the presence of Trp complexed by the HA supra-structure assures and enlarges the in vitro biostimulant action of Trp by delaying fast Trp degradation, thus promoting a more sustained effect [25].

In this framework, the aim of our study is to investigate whether the granulation of micronized RP along with (HA-Trp) complex is able to increase the short-term fertilizer action of RP by improving $\mathrm{P}$ solubilization rates in the rhizosphere. Our working hypothesis was that the potential increase in soil microbial activity, related enzyme activities, and local $\mathrm{pH}$ acidification in the physical rhizospheric environment surrounding RP granule triggered by HA-Trp might increase the rate of P mobilization from water-insoluble P in RP to the soil solution, thus enhancing short-term RP fertilizer efficiency. With this aim, we have investigated the effect of a granulated fertilizer made from RP and coated with (HA-Trp) (RP/ (HA-Trp)) and corresponding control treatments including RP coated with Trp alone (RP/Trp), RP, and SSP, on the early yield and $\mathrm{P}$ leaf concentration (1-3 months) of ray grass (Lolium perenne) cultivated in pots containing an acidic soil. These studies were complemented by soil incubation experiments carried out in order to evaluate the differential action of all treatments on soil microbial activity and potentially plant-available $P$.

\section{Methods}

Physico-chemical features of RP, SSP, HA, and Trp

The RP and SSP granulated samples (average size distribution $90 \%$ between 2 and $4 \mathrm{~mm}$ of granule diameter) were obtained from Timac Agro Fertilizer plant in Lodosa (Spain). Samples of granulated RP/Trp and RP/ (HA-Trp) were obtained by coating RP granules with a solution of vegetal oil containing talc and the edaphic biostimulant, while RP and SSP were coated with vegetal oil and talc. The concentration of $\mathrm{P}$ expressed as $\mathrm{P}_{2} \mathrm{O}_{5}$ of the different fertilizers were RP (29\%), RP/Trp (29\%), $\mathrm{RP} /(\mathrm{HA}-\mathrm{Trp})(29 \%)$, and SSP (17\%). In the case of RPbased fertilizers, $\mathrm{P}$ is not soluble in water (it is mainly apatite), while SSP contains water-soluble P (mainly monocalcium phosphate).

HA-Trp heteromolecular complex was obtained by reaction of potassium-iron humate and Trp at $\mathrm{pH} 6$ and room temperature as described in [25].

The leonardite HA employed for the preparation of HA-Trp complexes was extracted, purified, and characterized as described in [26, 27]. Elemental analysis revealed that the average chemical composition of HA was $51 \% \mathrm{C}, 1.2 \% \mathrm{~N}, 2.6 \% \mathrm{H}$, and $45.2 \% \mathrm{O}$. Regarding the distribution of the different functional C-types, ${ }^{13} \mathrm{C}$ NMR studies indicated that HA contained $32 \%$ alkyl C, $9 \%$ O-alkyl C, $43 \%$ aromatic C, $13 \%$ phenolic C, and $16 \%$ carbonyl C. Concerning the size distributions of the different humic samples, the HPSEC study showed a main peak with a maximum corresponding to an apparent MW of $2.3 \times 10^{4} \mathrm{Da}$, a shoulder corresponding to an apparent MW of $5.8 \times 10^{3} \mathrm{Da}$, and a third minor peak related to a fraction with average apparent MW of $1.1 \times 10^{3} \mathrm{Da}$.

Samples of $\operatorname{Trp}(99.9 \%)$ were obtained from Timac Agro Spain.

\section{Physico-chemical features of the acid soil employed in soil incubation and soil-plant studies}

An acidic soil from Egozkue (Navarra, Spain), with low potential plant-available $\mathrm{P}$ concentration, was used in the experiments. Egozkue is a small village placed in the north of Navarra. Soils in Egozkue are mainly acidic and poor in organic matter; pluviometry is around $1500 \mathrm{l}$ per year and day/night winter temperature is $10{ }^{\circ} \mathrm{C}$ on average. The soil was air-dried and sieved at $2 \mathrm{~mm}$. The final sample was analyzed using Spanish-official analytical methods [1, and references therein] (Table 1). Briefly, 
Table 1 Physico-chemical features of Egozkue soil

\begin{tabular}{|c|c|}
\hline Conductivity $\left(\mu \mathrm{S} \mathrm{cm}^{-1}\right)$ & 24.0 \\
\hline $\mathrm{pH}$ & 5.60 \\
\hline Extractable $\mathrm{P}\left(\mathrm{mg} \mathrm{kg}^{-1}\right)^{\mathrm{a}}$ & 4.02 \\
\hline $\left.\mathrm{K}(\mathrm{mmol} \mathrm{kg})^{-1}\right)^{\mathrm{a}}$ & 1.20 \\
\hline $\left.\mathrm{Mg}(\mathrm{mmol} \mathrm{kg})^{-1}\right)^{\mathrm{a}}$ & 3.50 \\
\hline $\mathrm{Ca}\left(\mathrm{mmol} \mathrm{kg}{ }^{-1}\right)^{\mathrm{a}}$ & 17.4 \\
\hline $\left.\mathrm{Na}(\mathrm{mmol} \mathrm{kg})^{-1}\right)^{\mathrm{a}}$ & 2.50 \\
\hline $\left.\mathrm{Fe}(\mathrm{mmol} \mathrm{kg})^{-1}\right)^{\mathrm{b}}$ & 0.49 \\
\hline $\left.\mathrm{Mn}(\mathrm{mmol} \mathrm{kg})^{-1}\right)^{\mathrm{b}}$ & 0.35 \\
\hline $\mathrm{Cu}\left(\mathrm{mmol} \mathrm{kg}{ }^{-1}\right)^{\mathrm{b}}$ & 0.003 \\
\hline $\left.\mathrm{Zn}(\mathrm{mmol} \mathrm{kg})^{-1}\right)^{\mathrm{b}}$ & 0.003 \\
\hline $\left.\mathrm{Mo}(\mathrm{mmol} \mathrm{kg})^{-1}\right)^{\mathrm{b}}$ & Under detection limits \\
\hline Organic Matter $\left(\mathrm{g} \mathrm{kg}^{-1}\right)$ & 0.10 \\
\hline Total $\mathrm{CaCO}_{3}\left(\mathrm{~g} \mathrm{~kg}^{-1}\right)$ & 0.000 \\
\hline Sand $(\%)$ & 15.0 \\
\hline Silt (\%) & 44.0 \\
\hline Clay (\%) & 41.0 \\
\hline
\end{tabular}

a Mehlich-1

b DTPA

soil particle size composition was determined by densitometry (Bouyoucos method); total $\mathrm{N}$ was determined by LECO CHN elemental analyzer; $\mathrm{K}, \mathrm{Mg}, \mathrm{Ca}$, and $\mathrm{Na}$ were extracted with a $40 \mathrm{mM} \mathrm{HCl}$ and $10 \mathrm{mM} \mathrm{H}_{2} \mathrm{SO}_{4}$ solution (Mehlich I extractant) and further analyzed using ICP-OES; micronutrients ( $\mathrm{Fe}, \mathrm{Cu}, \mathrm{Zn}$, and $\mathrm{Mn}$ ) were analyzed following extraction with a solution of DTPA $5 \mathrm{mM}$ [28] using ICP-OES; organic matter was determined by dichromate oxidation method [29]; total carbonates were measured with a Bernard calcimeter method. The $\mathrm{pH}$ and electrolytic conductivity were measured using specific electrodes in water (1:2.5 soil/water ratio). Molibdate was analyzed in the DTPA-water extract using ICP-OES.

\section{Soil incubation studies for the evaluation of plant-available $P$ in soil \\ Treatments}

Five repetitions for each treatment and a control without $P$ treatment were used. The test consisted of SSP, RP, and RP complemented with two different edaphic biostimulants incorporated during the granule coating process. The two edaphic biostimulants considered in the study were as follows:

Trp, a precursor of auxin biosynthesis in soils and plants ( $1 \%$ in the formulation with RP);

(HA-Trp), a heteromolecular complex of HA and Trp through electropositive bridges [25] (2:1 of HA:Trp ratio). The final dose of (HA-Trp) in the formulation was $3 \%$.
Control treatments included native soil without any treatment (blank, B), soil plus RP, and soil plus SSP. Preliminary studies conducted in our laboratory showed that control treatments including the soil plus Trp or (HA-Trp) without RP at concentrations equivalent to those involved in $\mathrm{RP} / \mathrm{Trp}$ and $\mathrm{RP} /(\mathrm{HA}-\mathrm{Trp})$ treatments did not present results different from those of the control without any treatment concerning soil-related parameters and plant growth rates. For this reason, we have not included these controls (soil plus Trp or (HA-Trp), without RP) in data presentation and further discussion. The concentration of $\mathrm{P}$ applied to the soil in the experiments is described below.

\section{Soil incubation experiments for the evaluation of plant-available $P$ in soil}

A mixture of $100 \mathrm{~g}$ of soil and $7 \mathrm{~g}$ of perlite was placed in $150-\mathrm{mL}$ plastic pots. The different treatments were added to the pot and the content was intensively mixed. A fertilizer rate of $150 \mathrm{mg} \mathrm{P} \mathrm{kg}^{-1}$ soil was used for all treatments and positive and negative controls. A control without added $\mathrm{P}$ was also used (B). Treated soil samples were homogenized and supplied with type I de-ionized water to reach soil field capacity, which was previously determined by moistening a soil column and allowing it to drain freely. Pots were closed and allowed to stand at ambient temperature in the dark. Samples corresponding to five replications were taken after 10, 20, and 30 days from the onset of the treatments and air-dried for analysis. Pots were opened every day to avoid microbial life inhibition and anaerobic processes.

\section{Analysis of plant-available $P$ fractions in control and treatments}

The total potentially plant-available $\mathrm{P}$ in samples of incubated soil was evaluated using the anion-exchange resin-extractable $\mathrm{P}[30,31]$. Soil samples were taken for analysis after 10,20, and 30 days from the onset of treatments. The amount of P desorbed by an anion-exchange resin was determined using the method of Sibbesen [30] with slight modifications. The resin used was 20-50 mesh Dowex $1 \times 4$ anion-exchange material in chloride form. An amount of $0.6 \mathrm{~g}$ of air-dried soil was placed in a $50-\mathrm{mL}$ plastic tube. A volume of $30 \mathrm{~mL}$ of de-ionized water and $2.2 \mathrm{~g}$ of resin, held in a nylon bag, were added to the soil ample. Following shaking at the maximum possible speed for $2.5 \mathrm{~h}$, the resin bag was withdrawn, the soil suspension centrifuged, and the solution discarded. The nylon bag was then rinsed with water and P eluted with $30 \mathrm{~mL}$ of $0.5 \mathrm{M} \mathrm{HCl}$ with shaking at the maximum speed for $30 \mathrm{~min}$. Another $30 \mathrm{~mL}$ of $0.5 \mathrm{M} \mathrm{HCl}$ was then added and shaking applied to complete $\mathrm{P}$ elution. The 
two $\mathrm{HCl}$ solutions were filtered and analyzed by ICPOES. This $\mathrm{P}$ fraction was designated plant-available $\mathrm{P}$.

\section{Soil incubation studies for the evaluation of soil microbial activity}

Both the fertilizer treatments and the concentration of fertilizer used were similar to those employed for the evaluation of plant-available $P$, and described above.

Two different assays were carried out in order to measure microbial activity: the FDA method and $\mathrm{CO}_{2}$ soil production [32, 33].

Soil incubations were carried out as described below.

Closed 0.5-L pots with a mixture of $100 \mathrm{~g}$ of soil-7 g of perlite and the different controls and treatments were irrigated with $43 \mathrm{~g}$ of water (at field capacity) and maintained at $25^{\circ} \mathrm{C}$. Samples for analysis were taken after 7 , 14,21 , and 28 days. Two replicates for each treatment were used.

Hydrolysis of fluorescein diacetate $\left[3^{\prime}, 6^{\prime}\right.$-diacetylfluorescein (FDA)] [32]: Two grams of air-dried soil was placed in a $125-\mathrm{ml}$ Erlenmeyer flask. $50 \mathrm{ml}$ of $60 \mathrm{mM}$ sodium phosphate buffer, $\mathrm{pH} 7.6$, and $0.50 \mathrm{ml}$ of $4.9 \mathrm{mM}$ FDA lipase substrate solution (20 mg FDA lipase substrate in $10 \mathrm{ml}$ acetone) were added. After mixing, samples were incubated for $1 \mathrm{~h}$ at $25^{\circ} \mathrm{C}$. Then $10 \mathrm{ml}$ of acetone was added to the suspension to stop FDA hydrolysis. Samples were filtered through Whatman No. 2 filter paper. The absorbance was measured on a spectrophotometer (HP-8453) at a wavelength of $490 \mathrm{~nm}$.

Measurement of $\mathrm{CO}_{2}$ release from soil by titration method according to Anderson [33]: A vial of $5 \mathrm{ml}$ of $1 \mathrm{M} \mathrm{KOH}$ was placed in each closed 0.5 -L pots. The alkali traps were changed and titrated at 7, 14, 21, and 28 days. Unreacted alkali in the $\mathrm{KOH}$ traps was back-titrated with $0.4 \mathrm{M} \mathrm{HCl}$ to determine the $\mathrm{CO}_{2}$ release by microbial respiration.

\section{Soil-plant experiments}

Experiments were carried out in a greenhouse under controlled temperature and lighting conditions. A $24 / 18{ }^{\circ} \mathrm{C}$ day/night temperature regime and a relative humidity of $40-60 \%$ were used.

Five replicates of $500 \mathrm{~g}$ of soil were blended with the different treatments: control without added P, SSP, RP, $\mathrm{RP} / \operatorname{Trp}(\operatorname{Trp})$, and $\mathrm{RP} /(\mathrm{HA}-\operatorname{Trp})$. In order to prepare the soil-fertilizer mixture, a Thermomix at maximum power for $5 \mathrm{~s}$ was used prior to the placement of the soil in plastic pots. Then, each soil-fertilizer mixture was carefully blended with $50 \mathrm{~g}$ of perlite and supplied with 10 seeds of ray grass (Lolium sp.) on pot surface $\left(113 \mathrm{~cm}^{2}\right)$. The $\mathrm{P}$ addition rates used were 10,30 , and $50 \mathrm{mg} \mathrm{P} \mathrm{kg}-1$ soil. As for the other nutrients, $200 \mathrm{mg} \mathrm{kg}^{-1}$ soil $\mathrm{N}$ and
$200 \mathrm{mg} \mathrm{kg}{ }^{-1} \mathrm{~K}$ soil were added as urea and potassium chloride in order to complete macronutrient fertilization. Finally, $0.4 \mathrm{mg} \mathrm{kg}^{-1}$ soil of Mo as sodium molibdate was also added to prevent a potential deficiency of Mo. The shoots corresponding to each pot were consecutively harvested at the end of the month for 3 months after seed germination. Once analyzed for fresh matter, shoots were dried in an oven at $40{ }^{\circ} \mathrm{C}$ for 3 days to determine dry matter. Next, the dry shoots were homogenized in a mill and sub-samples attacked with $\mathrm{HNO}_{3}$ and $\mathrm{H}_{2} \mathrm{O}_{2}$, and digested in a microwave oven, to determine $\mathrm{P}$ by ICP-OES as described in [27].

\section{Statistical analyses}

All experimental results were subjected to multiple pairwise comparisons between treatments, using Fisher's least significant difference (LSD) post hoc test in a oneway ANOVA method with the overall $\alpha$-level set at 0.05 .

\section{Results and discussion}

\section{Association of RP with HA-Trp or Trp increased}

both soil-available $P$ and soil microbial activity, compared with RP

Our results clearly show that SSP, RP/Trp, and RP/ (HA-Trp) caused a prompt (after 10 days) and significant increase in the concentration of plant-available $\mathrm{P}$ in the soil with respect to RP and native soil (Table 2). This increase, however, was transient and decreased after 20 and 30 days to RP levels (Table 2). In principle, this decrease in plant-available $\mathrm{P}$ was expected as the absence of a sink for available P in the soil system (such as plant roots) leads to an increase in plant-available $P$ in soil solution that, in turn, may cause a feedback inhibition of those processes and enzyme activities involved in the P mobilization mechanisms activated by these formulations [22]. In fact, some authors have reported that an increase in the concentration of $\mathrm{P}$ in water-soluble $\mathrm{P}$ was associated with a decrease in $\mathrm{CO}_{2}$ soil production by an inhibition of soil microbial activity [34-36]. This fact was also linked to significant decreases in soil enzymatic activities, including those related to different types of soil phosphatases [37]. However, other mechanisms, such as phosphate precipitation or phosphate absorption, can also contribute to the plant-available $\mathrm{P}$ decline with time.

While the increase in plant-available $\mathrm{P}$ is easily explained for SSP since it has water-soluble phosphate, in the case of RP/Trp and RP/(HA-Trp) this fact has to be related to some kind of process leading to $\mathrm{P}$ solubilization from RP. These processes are normally related to changes in the activity of P-solubilizing microbiota [18]. Our studies showed that both Trp and HA-Trp associated with RP caused a significant increase in soil 
Table 2 Time-course variation of soil plant-available $P$ $\left(\mathrm{mg} \mathrm{kg}^{-1}\right)$ measured by the resin method

\begin{tabular}{llllll}
\hline Time/days & \multicolumn{5}{l}{ Treatments } \\
\cline { 2 - 6 } Days & $\mathbf{B}$ & $\mathbf{R P}$ & SSP & RP/Trp & RP/(HA-Trp) \\
\hline 10 & $3.7 \mathrm{aA}$ & $19.7 \mathrm{bA}$ & $33.6 \mathrm{cB}$ & $46.9 \mathrm{cB}$ & $33.2 \mathrm{cB}$ \\
20 & $11.5 \mathrm{aB}$ & $24.2 \mathrm{cA}$ & $21.7 \mathrm{cB}$ & $16.0 \mathrm{bcA}$ & $13.5 \mathrm{bA}$ \\
30 & $5.8 \mathrm{aA}$ & $17.3 \mathrm{bA}$ & $14.6 \mathrm{bA}$ & $12.3 \mathrm{bA}$ & $17.0 \mathrm{bA}$ \\
\hline
\end{tabular}

Data followed by the same lowercase letter in each row or by the same uppercase letter in each column are not statistically different from each other (Fisher's test, $P<0.05$ ). Capital letters are used for differences with time within each treatment. Lowercase letters are used for differences among treatments within each time

microbial activity compared with the native soil, SSP, and RP (Table 3). This fact was very clear when $\mathrm{CO}_{2}$ soil production was evaluated, while the results for FDA hydrolysis were less conclusive (Table 3 ). These differences between methods have also been described by other authors, and seem to be related to the fact that FDA hydrolysis method only includes specific families of soil hydrolases [38-40] and, therefore, it can give an incomplete evaluation of soil microbial activity in some soil types. It is for this reason that traditional methods such as the analysis of soil $\mathrm{CO}_{2}$ production might be more sensitive for the evaluation of whole soil microbial activity changes. In any case, these results suggest that the increase in soil microbial activity plays an important role in the P-solubilizing action of Trp and HA-Trp from RP.

\section{Association of RP with HA-Trp, but not with Trp alone, produced a sustained increase in shoot dry matter production up to levels similar to those of SSP}

The results clearly showed that the short-term action of $\mathrm{RP}$ on both shoot dry matter and P fertilizer efficiency is significantly lower than that of SSP for all harvests and higher $\mathrm{P}$ doses (30 and $50 \mathrm{mg} \mathrm{kg}^{-1}$ ) (Fig. 1). In line with these results, shoot dry matter values for RP only presented a dose-response pattern with added $\mathrm{P}$ rates at the first harvest, while SSP maintained a dose-response pattern for all harvests (Fig. 1). These results confirm that our experimental model is adequate to investigate the main issues posed by the study.

As for the ability of the different fertilizers to enhance shoot dry matter production, although both RP/Trp and $\mathrm{RP} /(\mathrm{HA}-\mathrm{Trp})$ presented very similar results to each other in soil incubation studies, HA-Trp-but not Trp alone-presented a beneficial action of the efficiency of RP to enhance shoot dry matter production when all harvests are considered (Fig. 1). In fact, even though RP/Trp caused a prompt and significant increase in shoot dry matter production at the first harvest and for the higher doses of P (30 and $50 \mathrm{mg} \mathrm{kg}{ }^{-1}$ ), this effect disappeared at the following harvests. Conversely, both SSP and RP/ (HA-Trp) presented higher increases in shoot dry matter production than the control and RP for the second and third harvests (Fig. 1). Thus, the association of RP with (HA-Trp) caused a significant and sustained increase in shoot dry matter production compared with RP for all harvest times, with this increase being similar to that

Table 3 Time-course variation of FDA hydrolysis and $\mathrm{CO}_{2}$ soil production

\begin{tabular}{|c|c|c|c|c|}
\hline & \multicolumn{4}{|c|}{ 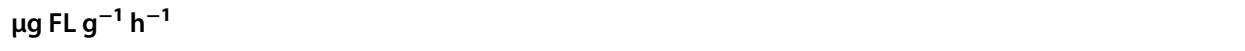 } \\
\hline & 7 days & 14 days & 21 days & 28 days \\
\hline \multicolumn{5}{|l|}{ FDA hydrolysis } \\
\hline $\mathrm{B}$ & 1.88 & 2.76 & 3.71 & $4.08 \mathrm{a}$ \\
\hline $\mathrm{RP}$ & 1.80 & 2.73 & 3.59 & $4.02 \mathrm{a}$ \\
\hline SSP & 1.58 & 2.76 & 3.55 & $3.98 \mathrm{a}$ \\
\hline $\mathrm{RP} / \mathrm{Trp}$ & 2.04 & 3.03 & 4.00 & $4.41 \mathrm{C}$ \\
\hline \multirow[t]{3}{*}{$\mathrm{RP} /(\mathrm{HA}-\mathrm{Trp})$} & 1.71 & 2.74 & 3.70 & $4.15 b$ \\
\hline & \multicolumn{4}{|c|}{$\mathrm{mgCO}_{2} \mathrm{~kg}^{-1}$ soil } \\
\hline & 7 days & 14 days & 21 days & 28 days \\
\hline \multicolumn{5}{|c|}{$\mathrm{CO}_{2}$ soil production } \\
\hline B & 83.6 & 123 & 147 & $165 a$ \\
\hline $\mathrm{RP}$ & 117 & 154 & 170 & $203 a$ \\
\hline SSP & 81.4 & 128 & 152 & $178 a$ \\
\hline $\mathrm{RP} / \mathrm{Trp}$ & 96.8 & 154 & 187 & $229 b$ \\
\hline RP/(HA-Trp) & 123 & 167 & 202 & $240 b$ \\
\hline
\end{tabular}

Data followed by the same lowercase letter in each column are not statistically different from each other (Fisher's test, $P<0.05$ ) 


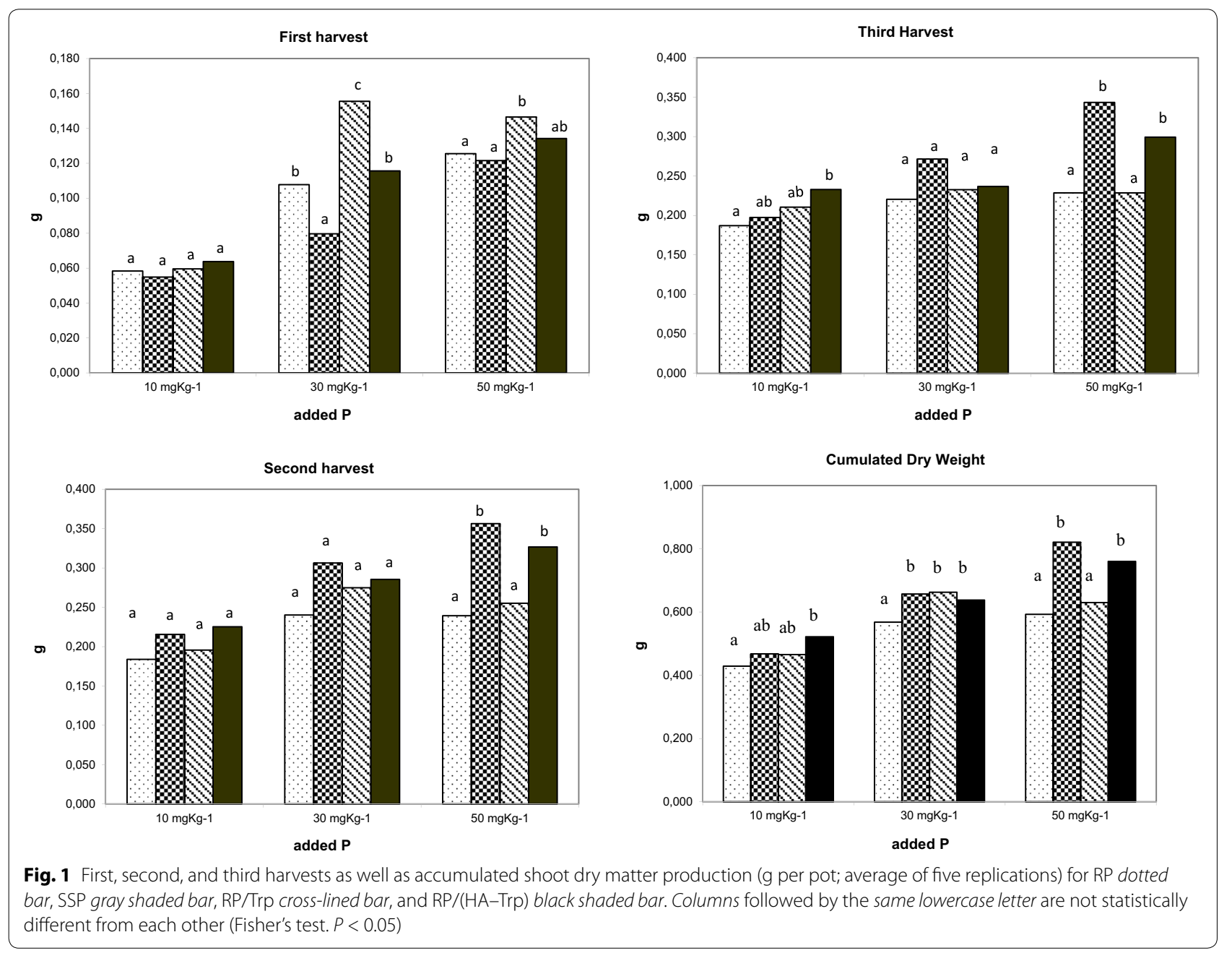

caused by SSP (Fig. 1). These results were clearer for the highest dose of $\mathrm{P}$ added to the soil $\left(50 \mathrm{mg} \mathrm{kg}^{-1}\right)$ (Fig. 1). Differences between RP/Trp and RP/(HA-Trp) might be a consequence of an effect of HA on RP solubilization either directly or through an increase in soil microbial activity. However, preliminary studies using P fertilizers containing $1 \%$ HA did not show any effect on both P bioavailability and shoot growth in several soil types [41]. In some way, these results were expected since the concentration of $\mathrm{P}$ applied to soil $\left(50 \mathrm{mg} \mathrm{Kg}{ }^{-1}\right)$ involved the soil application of very low concentrations of HA (lower than $40 \mathrm{mg} \mathrm{kg}^{-1}$ ). However, these studies showed that when HA was applied forming stable and soluble complexes with $\mathrm{Zn}$ or $\mathrm{Cu}$, a clear increase in plant growth was observed resulting from an improvement in the plant uptake of both micronutrients [42]. Although in our study we do not use humic metal complexes, some action of HA in RP fertilizers improving micronutrient plant nutrition cannot be ruled out. Another factor influencing the differential effect of HA-Trp compared with Trp alone might result from the presence of Fe in HA-Trp complexes. However, taking into account that the amount of plant-available Fe in Egozcue soil is quite high (Table 1), it is rather improbable that the Fe added with HA-Trp in RP/(HA-Trp) treatment can cause significant changes in plant growth. Finally, another possible explanation for these results may relate to some type of synergic action of HA and Trp when applied together. In fact, Trp complexation in HA supramolecule might delay its conversion in indolacetic acid (IAA) (and, therefore, IAA degradation) by favoring a slow release of $\operatorname{Trp}$ to the rhizospheric environment [23-25]. This hypothesis might also contribute to explain the results obtained, but further experiments using this experimental model are needed in order to establish its validity.

Taking into account that the effect of RP/(HA-Trp) on shoot dry matter production was consistent with the increase in soil microbial activity caused for this fertilizer in soil incubation studies (Table 3), this effect might be linked to some kind of secondary action of (HA-Trp) on 
local soil features in granule environment resulting from the enhancement in soil microbiota activity, which in turn favor P solubilization from RP.

Regarding the relationships between shoot dry weight production and the concentration of $\mathrm{P}$ in the shoot, the values of shoot $\mathrm{P}$ concentration showed that $\mathrm{RP} /$ (HA-Trp) increased this parameter with respect to RP. In addition, these effects tended to be lower than those associated with SSP only at the first harvest (Fig. 2). The fact that the differences of shoot dry matter production between RP/(HA-Trp) and SSP were not different from each other led to the fact that the fertilizer efficiency of $\mathrm{RP} /(\mathrm{HA}-\mathrm{Trp})$ and SSP was quite similar to each other and significantly higher than that of RP principally for the highest $\mathrm{P}$ dose $\left(50 \mathrm{mg} \mathrm{kg}^{-1}\right)$ and third harvest (Table 4).

The fact that plants treated with RP/Trp have the highest concentration of $\mathrm{P}$ in the shoot for the second and third harvests probably derives from a concentration effect associated with the low production of shoot dry matter produced by this fertilizer (Figs. 1, 2). This fact was also reflected in the low values of RP/Trp fertilizer efficiency parameters (Table 4).

Finally, we did not observe clear differences between the efficiency of plant $\mathrm{P}$ utilization in the shoot for SSP and $\mathrm{RP} /(\mathrm{HA}-\mathrm{Trp})$, although in both cases this parameter was higher than those for RP and RP-Trp, principally for the highest $P$ dose $\left(50 \mathrm{mg} \mathrm{kg}^{-1}\right)$ (Table 5). This fact indicated that plant metabolism was not differently affected by SSP and RP/(HA-Trp), thus suggesting that HA-Trp complex had not direct effect on plant metabolism at the doses associated with RP/(HA-Trp) fertilizer rates.

\section{Conclusion}

Summarizing, the results here described show that the association of RP with an organic complex formed by HA and Trp linked to each other through electropositive bridges (mainly, proton or metal, in this case Fe) avoided the short-term differences in agronomical efficacy

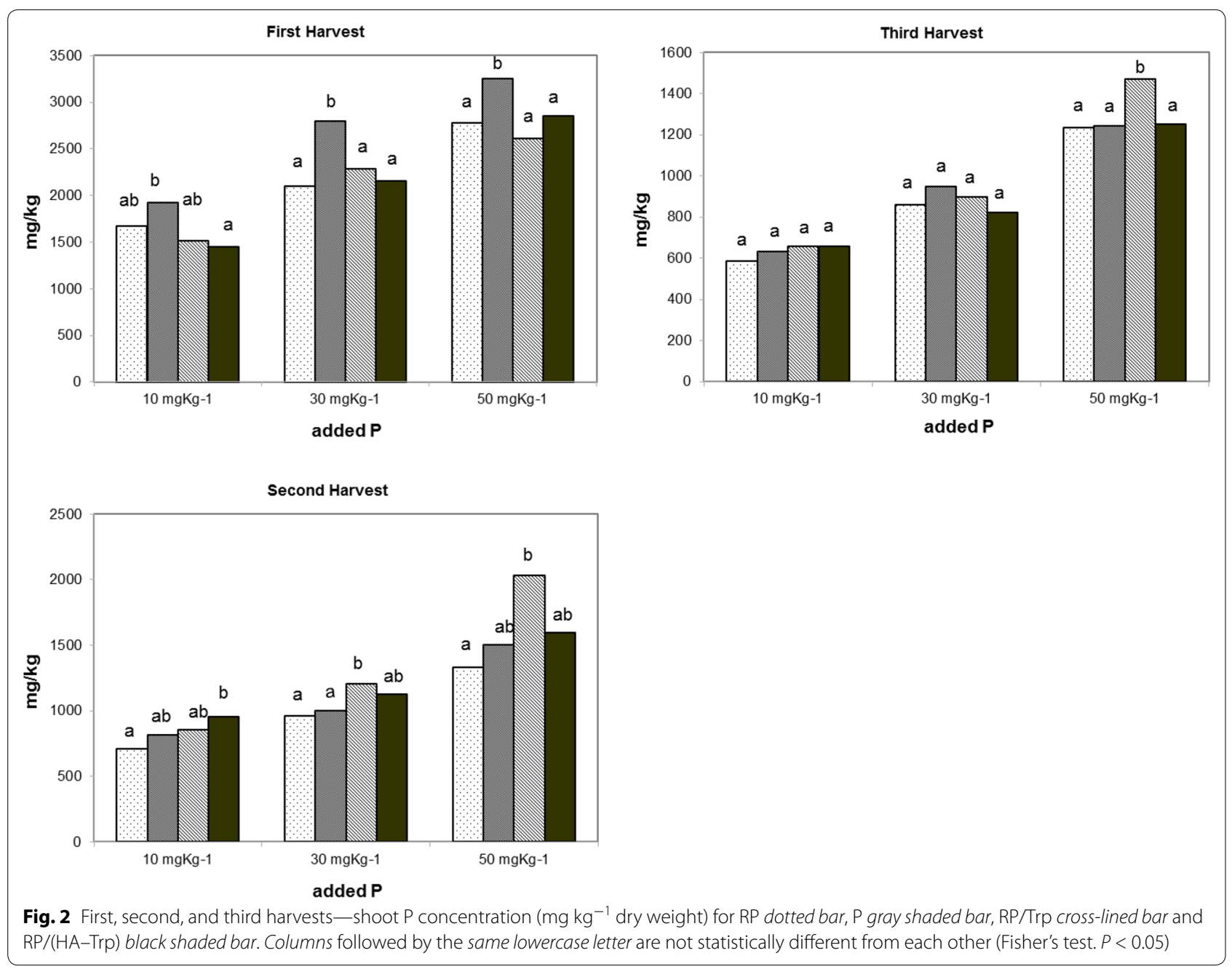


Table 4 Fertilizer efficiency index defined by [(dry matter production) $\times 100] /($ added $P$ to the soil)

\begin{tabular}{|c|c|c|c|c|c|c|c|c|c|c|c|c|}
\hline \multirow{2}{*}{$\begin{array}{l}\text { Treatments } \\
\text { Added } \mathrm{P} \text { ( } \mathrm{mg} \mathrm{kg}^{-1} \text { soil) }\end{array}$} & \multicolumn{3}{|l|}{$\mathrm{RP}$} & \multicolumn{3}{|l|}{ SSP } & \multicolumn{3}{|l|}{$\mathrm{RP} / \mathrm{Trp}$} & \multicolumn{3}{|c|}{ RP/(HA-Trp) } \\
\hline & 10 & 30 & 50 & 10 & 30 & 50 & 10 & 30 & 50 & 10 & 30 & 50 \\
\hline \multicolumn{13}{|l|}{ Harvest } \\
\hline First & 5.83 & 0.36 & 0.25 & 5.49 & 0.27 & 0.24 & 5.95 & 0.52 & 0.29 & 6.37 & 0.39 & 0.27 \\
\hline Second & $18.37 a$ & $0.80 c$ & 0.48 & $21.56 b$ & $1.02 d$ & 0.71 & $19.58 b$ & $0.92 d$ & 0.51 & $22.53 b$ & $0.95 d$ & 0.65 \\
\hline Third & $18.70 a$ & $0.73 c$ & $0.46 d$ & $19.73 b$ & $0.90 d$ & $0.69 \mathrm{e}$ & $21.04 b$ & $0.77 c$ & $0.46 \mathrm{~d}$ & $23.29 b$ & $0.79 c$ & $0.60 \mathrm{e}$ \\
\hline
\end{tabular}

Data followed by the same lowercase letter in each row are not statistically different from each other (Fisher's test, $P<0.05$ )

Table 5 Plant $P$ utilization efficiency index defined by $[($ dry matter production) $\times 10,000] /($ shoot $P$ concentration)

\begin{tabular}{|c|c|c|c|c|c|c|c|c|c|c|c|c|}
\hline \multirow{2}{*}{$\begin{array}{l}\text { Treatments } \\
\text { Added } \mathrm{P} \text { ( } \mathrm{mg} \mathrm{kg}^{-1} \text { soil) }\end{array}$} & \multicolumn{3}{|l|}{$\mathrm{RP}$} & \multicolumn{3}{|l|}{ SSP } & \multicolumn{3}{|c|}{$\mathrm{RP} / \mathrm{Trp}$} & \multicolumn{3}{|c|}{ RP/(HA-Trp) } \\
\hline & 10 & 30 & 50 & 10 & 30 & 50 & 10 & 30 & 50 & 10 & 30 & 50 \\
\hline \multicolumn{13}{|l|}{ Harvest } \\
\hline First & 0.35 & 0.51 & 0.45 & 0.29 & 0.28 & 0.37 & 0.39 & 0.68 & 0.56 & 0.44 & 0.54 & 0.47 \\
\hline Second & 2.60 & 2.50 & $1.80 \mathrm{~b}$ & 2.65 & 3.06 & $2.37 c$ & 2.29 & 2.29 & $1.26 a$ & 2.35 & 2.53 & $2.04 c$ \\
\hline Third & 3.21 & 2.56 & $1.85 \mathrm{a}$ & 3.14 & 2.86 & $2.76 b$ & 3.21 & 2.60 & $1.56 a$ & 3.55 & 2.89 & $2.39 b$ \\
\hline
\end{tabular}

Data followed by the same lowercase letter in each row are not statistically different from each other (Fisher's test, $P<0.05$ )

existing between RP and SSP, thus improving the starter action of RP-based fertilizers. This issue is very relevant because the main negative feature of RP as a P source for pastures cultivated in acidic soils is its poor short-term (1-year) effect in comparison with that of water-soluble P fertilizers, thus negatively affecting yield and quality [1]. However, the long-term action (3-4 years) of RP-based fertilizers as a $\mathrm{P}$ source for pastures cultivated in acidic soils may be even more efficient than that of water-soluble $\mathrm{P}$ fertilizers $[1,4,5]$. This fact indicates that both fertilizers (HA-Trp activated RP and SSP) may be rather complementary in a whole fertilization plan for pastures in acidic soils.

\section{Authors' contributions \\ LF principally but also RB, OU, and JE have made the experimental work and contributed to MS preparation; RB, OU, JE, and PMA contributed to the experi- mental design; JCY contributed to the discussion of results; and JMG contrib- uted to the design of the experiments, discussion of results, MS preparation, and final writing. All authors read and approved the final manuscript.}

\section{Author details}

${ }^{1}$ Institute of Agro-Biotechnology, Public University of Navarra-CSIC-Government of Navarra, Campus de Arrosadía, 31006 Pamplona, Navarra, Spain. 2 Department of Environmental Biology (Agricultural Chemistry and Biology Group), Faculty of Sciences, University of Navarra, 31080 Pamplona, Spain.

${ }^{3}$ Centre Mondial d'Innovation (CMI), Roullier Group, Saint Malo, France.

${ }^{4}$ Department of Environmental Biology, Agricultural Chemistry and Biology Group, Faculties of Sciences and Pharmacy, University of Navarra, C/Irunlarrea 1, 31080 Pamplona, Navarra, Spain.

\section{Acknowledgements}

This Research Project has been supported by a Grant from CDTI and Government of Navarra, as well the Roullier Group. We would like to thank Paul W. Miller for kindly improving the English of the manuscript.

\section{Competing interests}

The authors declare that they have no competing interests.

Received: 7 September 2015 Accepted: 1 March 2016

Published online: 12 March 2016

\section{References}

1. Domínguez Vivancos A. Tratado de fertilización. Madrid: Mundi-Prensa; 1996.

2. Van Straaten P. Rocks for crops, Agrominerals of sub-Saharan Africa. Guelph: University of Guelph; 2002.

3. He ZL, Baligar V, Martens DC, Ritchey KD, Elrashidi M. Effect of byproduct, nitrogen fertilizer, and zeolite on phosphate rock dissolution and extractable phosphorus in acid soil. Plant Soil. 1999;208:199-207.

4. Chien SH, Hammond LL. Agronomic effectiveness of partially acidulated phosphate rock as influenced by soil phosphorus-fixing capacity. Plant Soil. 1989;120:159-64.

5. Zoysa AKN, Loganathan P, Hedley MJ. Comparison of the agronomic effectiveness of a phosphate rock and triple superphosphate as phosphate fertilisers for tea (Camellia sinensis L.) on a strongly acidic Ultisol. Nutr Cyc Agroecosys. 2001;59:95-105.

6. Hammond LL, Chien SH, Roy AH, Mokwunye AU. Solubility and agronomic effectiveness of partially acidulated phosphate rocks as influenced by their iron and aluminium oxide content. Fert Res. 1989;19:93-8.

7. Ghani A, Rajan SSS. Differential availability of partially sulphuric and phosphoric acidulated phosphate rocks I plant response. Nutri Cyc Agroecosys. 1997:47:251-9.

8. McSweeney G, Charleston AG. Partially acidulated phosphate rocksreactions with water. Fert Res. 1985;8:75-83.

9. Menon RG, Chien SH, Hammond LL. Comparison of Bray I and Pi tests for evaluating plant-available phosphorus from soils treated with different partially acidulated phosphate rocks. Plant Soil. 1989;114:211-6.

10. Begum M, Narayanasamy G, Biswas DR. Phosphorus supplying capacity of phosphate rocks as influenced by compaction with water-soluble $P$ fertilizers. Nutr Cyc Agroecosys. 2004;68:73-84. 
11. Sisworo EL, Sisworo WH, Rasjid H, Rizal S (2002) The response to $p$-derived from phosphate rock and tsp by crops grown in a simulated crop rotation system. At Indonesia. 2002;28:19-30.

12. Gyaneshwar P, Naresh Kumar G, Parekh LJ, Poole PS. Role of soil microorganisms in improving P nutrition of plants. Plant Soil. 2002;245:83-93.

13. Jorquera MA, Hernández MT, Rengel Z, Marschner P, Mora ML. Isolation of culturable phosphobacteria with both phytate-mineralization and phosphate-solubilization activity from the rhizosphere of plants grown in a volcanic soil. Biol Fert Soil. 2004;44:1025-34

14. Malboobi MA, Owlia P, Behbahani M, Sarokhani E, Moradi S, Yakhchali B, Deljou A, Heravi KM. Solubilization of organic and inorganic phosphates by three highly efficient soil bacterial isolates. J Microb Biotech. 2009;25:1471-7.

15. Reyes I, Valery A, Valduz Z. Phosphate-solubilizing microorganisms isolated from rhizospheric and bulk soils of colonizer plants at an abandoned rock phosphate mine. Plant Soil. 2006;287:69-75.

16. Sundara B, Natarajan V, Hari K. Influence of phosphorus solubilizing bacteria on the changes in soil available phosphorus and sugarcane and sugar yields. Field Crop Res. 2002;77:43-9.

17. Ahemad M, Khan MS. Phosphate-solubilizing and plant-growth-promoting pseudomonas aeruginosa ps1 improves greengram performance in quizalafop-p-ethyl and clodinafop amended soil. Arch Environ Cont Toxicol. 2010;58:361-72.

18. de Freitas JR, Banerjee MR, Germida JJ. Phosphate-solubilizing rhizobacteria enhance the growth and yield but not phosphorus uptake of canola (Brassica napus L.). Biol Fert Soil. 1997;24:358-3641.

19. Zabihi HR, Savaghebi GR, Khavazi K, Ganjali A, Miransari M. Pseudomonas bacteria and phosphorous fertilization, affecting wheat (Triticum aestivum L.) yield and P uptake under greenhouse and field conditions. Acta Physiol Plant. 2010;33:145-52.

20. Tejada M, Benítez C, Parrado J. Application of biostimulants in benzo(a) pyrene polluted soils: short-time effects on soil biochemical properties. Appl Soil Ecol. 2011;50:21-6.

21. Rodríguez-Morgado B, Gómez I, Parrado J, García C, Hernández T, Tejada M. Accelerated degradation of PAHs using edaphic biostimulants obtained from sewage sludge and chicken feathers. J Hazard Mate. 2015;300:235-42.

22. Renella G, Landi L, Garcia-Mina JM, Giagnoni L, Nannipieri P. Microbial and hydrolase activity after release of indoleacetic acid and ethylene-polyamine precursors by a model root surface. App Soil Ecol. 2011;47:106-10.

23. Arshad M, Frankenberger WT Jr. Plant growth-regulating substances in the rhizosphere: microbial production and functions. Adv Agron. 1998;62:45-151.

24. San-Francisco S, Houdusse F, Zamarreño AM, Garnica M, Casanova E, Garcla-Mina JM. Effects of IAA and IAA precursors on the development, mineral nutrition, IAA content and free polyamine content of pepper plants cultivated in hydroponic conditions. Sci Hort. 2005;106:38-52.

25. García-Mina JM, Baigorri R, Zamarreño AM, Bacaicoa E, Fuentes M (2011) Heteromolecular metal-humic (chelate) complexes. ES Patent 2335562, EP Patent 1997793 and US Patent 20080221314.

26. Aguirre E, Lemenager D, Bacaicoa E, Fuentes M, Baigorri R, Zamarreno AM, Garcia-Mina JM. The root application of a purified leonardite humic acid modifies the transcriptional regulation of the main physiological root responses to Fe deficiency in Fe-sufficient cucumber plants. Plant Physiol Biochem. 2009:47:215-23.
27. Mora V, Bacaicoa E, Zamarreno AM, Aguirre E, Garnica M, Fuentes M, Garcia-Mina JM. Action of humic acid on promotion of cucumber shoot growth involves nitrate-related changes associated with the root-toshoot distribution of cytokinins, polyamines and mineral nutrients. J Plant Physiol. 2010;167:633-42.

28. Lindsay WL, Novell WA. Development of DTPA soil test for zinc; iron; manganese and copper. Soil Sci Soc Am J. 1978;42:6421-8.

29. Walkley A, Black IA. An examination of Degtjareff method for determining soil organic matter and a proposed modification of the chromic acid titration method. Soil Sci. 1934;34:29-38.

30. Sibbesen E. A simple ion-exchange resin procedure for extracting plantavailable elements from soil. Plant Soil. 1977;46:665-9.

31. Verma S, Subehia SK, Sharma SP. Phosphorus fractions in an acid soil continuously fertilized with mineral and organic fertilizers. Biol Fert Soil. 2005:41:295-300.

32. Schnurer J, Rosswall T. Fluorescein diacetate hydrolysis as a measure of total microbial activity in soil and litter. App Environ Microbiol. 1982;43:1256-61.

33. Anderson JPE. Soil respiration. In: Page AL, Miller RH, Keeney DR, editors. Methods of soil analysis, part 2. Madison: American Society of Agronomy; 1982. p. 831-71.

34. Amador JA, Jones RD. Nutrient limitations on microbial in peat soils with different total content respiration phosphorus. Soil Biol Biochem. 1993;25:793-801.

35. Smith VR. Moisture, carbon and inorganic nutrient controls of soil respiration at a sub-Antarctic island. Soil Biol Biochem. 2005;37:81-91.

36. Thirukkumaran CM, Parkinson D. Microbial respiration, biomass, metabolic quotient and litter decomposition in a lodgepole pine forest floor amended with nitrogen and phosphorous fertilizers. Soil Biol Biochem. 2010;32:59-66.

37. Baligar VC, Wright RJ, Hern JL. Enzyme activities in soil influenced by levels of applied sulphur and phosphorus. Com Soil Sci Plant Anal. 2005;36:1727-35.

38. Adam G, Duncan H. Development of a sensitive and rapid method for the measurement of total microbial activity using fluorescein diacetate (FDA) in a range of soils. Soil Biol Biochem. 2001;33:943-51.

39. Green VS, Stott DE, Diack M. Assay for fluorescein diacetate hydrolytic activity: optimization for soil samples. Soil Biol Biochem. 2006;38:693-701.

40. Sánchez-Monedero MA, Mondini C, Cayuela ML, Roig A, Contin M, De Nobili M. Fluorescein diacetate hydrolysis, respiration and microbial biomass in freshly amended soils. Biol Fert Soil. 2008;44:885-90.

41. Sanchez-Diaz M, Garcia-Mina JM. Effet de l'association chimique NPK MGcomplexe organique activé sur le development vegetal et l'assimilation de nutrients pour les plantes. Inab Rapp. 1994;72:1-7.

42. García-Mina JM, Antolín MC, Sanchez-Diaz M. Metal-humic complexes and plant micronutrient uptake: a study based on different plant species cultivated in diverse soil types. Plant Soil. 2004;258:57-68.

\section{Submit your manuscript to a SpringerOpen ${ }^{\circ}$ journal and benefit from:}

- Convenient online submission

- Rigorous peer review

- Immediate publication on acceptance

- Open access: articles freely available online

- High visibility within the field

- Retaining the copyright to your article

Submit your next manuscript at $>$ springeropen.com 